\title{
Sosialisasi Pencegahan Stunting Dengan Kenali Penyebabnya Di Desa Suka Mulya
}

\author{
Risa Pitriani, Liva Maita, Zainatul Faizah, Arlya Sri Merti
}

STIKes Hang Tuah Pekanbaru

\begin{abstract}
Stunting is a chronic condition that describes stunted growth due to long-term malnutrition as indicated by the index of body length for age $(P B / U)$ or height for age $(T B / U)$ with a z-score limit of less than -2 SD. increases beyond normal limits (Astari, 2015). This is because 80-90\% of the number of brain cells is formed from the time in the womb to the age of 2 years. The aim of this service is expected that the community understands that exclusive breastfeeding and fulfillment of nutrition are very important for babies and toddlers to avoid stunting. Methods of activity carried out by providing counseling, weighing weight and measuring $T B$, evaluating the material provided by asking the maeri again who has been explained. The results of the implementation have shown that from the presentation of the material, mothers can understand and understand the true benefits of complementary foods given to toddlers, so that it can reduce the incidence of stunting. It is recommended that community health centers be able to increase their attention to toddlers who have problems with nutritional status. As an evaluation prevention effort used by weighing and measuring height and also teaching mothers about giving complementary foods to babies properly.
\end{abstract}

Keywords: Stunting, Prevention, Causes

\begin{abstract}
ABSTRAK
Stunting merupakan kondisi kronis yang menggambarkan terhambatnya pertumbuhan karena malnutrisi jangka panjang yang ditandai dengan indeks panjang badan dibanding umur $(\mathrm{PB} / \mathrm{U})$ atau tinggi badan dibanding umur $(\mathrm{TB} / \mathrm{U})$ dengan batas $z$-score kurang dari -2 SD. naik melebihi batas normal (Astari,2015). Hal ini disebabkan karena 80-90\% jumlah sel otak terbentuk semenjak masa dalam kandungan sampai usia 2 tahun. Tujuan pengabdain ini diharapkan masyarakat mengerti bahwa ASI Eksklusif dan pemenuhan nutrisi sangat penting bagi bayi dan balita agar terhindar dari stunting. Metode kegiatan yang dilakukan dengan cara memberikan penyuluhan, melakukan penimbangan BB dan pengukuran TB, mengevaluasi materi yang diberikan dengan menanyakan kembali maeri yang sudah dijelaskan. Hasil pelaksanaan sudah terlihat bahawa dari penyajian materi, ibu-ibu dapat memahami dan mengerti tentang manfaat MP-ASI yang benar yang diberikan kepada balita, sehingga dapat menurunkan angka kejadian stunting. Disarankan kepada puskesmmas agar dapat meningkatkan perhatiannya kepada balita yang mempunyai masalah dengan status gizi. Sebagai upaya pencegahan evaluasi yang digunakan dengan melakukan penimbangan berat badan dan pengukuran tinggi badan dan juga mengajarkan ibu tentang pemberian MP-ASI pada bayi dengan benar.
\end{abstract}

Kata Kunci: Stunting, Pencegahan, Penyebab 


\section{PENDAHULUAN}

Stunting merupakan kondisi kronis yang menggambarkan terhambatnya pertumbuhan karena malnutrisi jangka panjang yang ditandai dengan indeks panjang badan dibanding umur $(\mathrm{PB} / \mathrm{U})$ atau tinggi badan dibanding umur $(\mathrm{TB} / \mathrm{U})$ dengan batas z-score kurang dari -2 SD (Kepmenkes RI,2010).

Secara global, prevalensi stunting pada anak menurun dari 39,7\% tahun 1990 menjadi 26,7\% pada tahun 2010. Angka ini diperkirakan akan mencapai 21,8 \% pada tahun 2020 . Prevalensi stunting di Afrika mengalami stagnasi sejak tahun 1990 sekitar 40\%, sementara di Asia menunjukkan penurunan dari $49 \%$ pada tahun 1990 menjadi 28\% pada tahun 2010 (Onis, 2011).

Prevalensi stunting di beberapa negara di Asia Tenggara, seperti Myanmar sebesar 35\%, Vietnam sebesar 23\%, dan Thailand sebesar $16 \%$. Prevalensi stunting di Indonesia Menurut Riset Kesehatan Dasar 2013 sebesar 37,2 persen, meningkat dari tahun 2010 sebesar 35,6\% dan pada tahun 2007 sebesar $36,8 \%$. Artinya, pertumbuhan tak maksimal diderita sekitar 8 juta anak di Indonesia, atau satu dari tiga anak di Indonesia (Riskesdas,2013). Prevalensi stunting bahkan lebih tinggi dibandingkan dengan permasalahan gizi pada balita lainnya seperti gizi kurang $(19,6 \%)$, kurus $(6,8 \%)$, dan gemuk $(11,9 \%)$ (Millennium Challenge Account Indonesia,2015).

Balita yang mengalami stunting meningkatkan risiko penurunan kemampuan intelektual, menghambatnya kemampuan motorik, produktivitas, dan peningkatan risiko penyakit degeneratif di masa mendatang.Hal ini dikarenakan anak stunting cenderung lebih rentan menjadi obesitas, karena orang dengan tubuh pendek berat badan idealnya juga rendah. Kenaikan berat badan beberapa kilogram saja bisa menjadikan Indeks Massa Tubuh (IMT) orang tersebut naik melebihi batas normal (Astari,2015).

Kekurangan gizi pada masa golden period (0-2 tahun), akan menyebabkan sel otak anak tidak tumbuh sempurna. Hal ini disebabkan karena 8090\% jumlah sel otak terbentuk semenjak masa dalam kandungan sampai usia 2 tahun. Apabila gangguan tersebut terus berlangsung maka akan terjadi penurunan skor tes IQ sebesar 10-13 point. Penurunan perkembangan IQ tersebut akan mengakibatkan terjadinya loss generation, artinya anak-anak tersebut akan menjadi beban bagi keluarga, masyarakat, dan pemerintah (I Dewa Nyoman,2002).

Masalah kekurangan gizi 1000 
HPK diawali dengan perlambatan atau retardasi pertumbuhan janin yang dikenal sebagai IUGR (Intra Uterine Growth Retardation). Janin akan tumbuh dan berkembang melalui pertambahan berat dan panjang badan, perkembangan otak serta organ-organ lainnya. Janin mempunyai plastisitas yang tinggi, artinya janin akan dengan mudah menyesuaikan diri terhadap perubahan lingkungannya baik yang menguntungkan maupun yang merugikan pada saat itu. Sekali perubahan tersebut terjadi, maka tidak dapat kembali ke keadaan semula. Perubahan tersebut merupakan interaksi antara gen yang sudah dibawa sejak awal kehidupan, dengan lingkungan barunya (Kemenko Kesra, 2013).

$$
\text { Banyak faktor yang }
$$

menyebabkan tingginya kejadian stunting pada balita.Faktor langsung yang berhubungan dengan stunting yaitu asupan makanan dan status kesehatan.Faktor tidak langsung yang berhubungan dengan stunting yaitu Pola pengasuhan, pelayanan kesehatan, faktor maternal dan lingkungan rumah tangga.Akar masalah yang menyebabkan kejadian stunting yaitu status ekonomi keluarga yang rendah (Semba and Bloem, 2001).

Asupan zat gizi yang tidak adekuat, terutama dari total energi, protein, lemak dan zat gizi mikro, berhubungan dengan defisit pertumbuhan fisik pada anak.Protein merupakan zat pengatur dalam tubuh manusia.Protein pada balita dibutuhkan untuk pemeliharaan jaringan, perubahan komposisi tubuh, dan untuk sintesis jaringan baru. Selain itu, protein juga dapat membentuk antibodi untuk menjaga daya tahan tubuh terhadap infeksi dan bahan-bahan asing yang masuk ke dalam tubuh.Kelaparan atau semi-kelaparan dapat mengubah komposisi tubuh.Protein tidak bertambah, tapi juga habis digunakan, sehingga massa sel tubuh berkurang. Malnutrisi dapat meningkatkan risiko infeksi, sedangkan infeksi dapat menyebabkan malnutrisi. Anak kurang gizi, daya tahan terhadap penyakitnya rendah, jatuh sakit dan akan menjadi semakin kurang gizi, sehingga mengurangi kapasitasnya untuk melawan penyakit (Maxwell, 2011).

\section{METODE KEGIATAN}

\section{Kerangka Pemecahan Masalah}

Metode yang digunakan dalam kegiatan pengabdian ini adalah penyuluhan, penyampaian mater, dan tanya jawab tentang pemahaman dari materi yang disampaikan. Materi yang disampaikan. Materi yang disampaikan seputar masalah Pencegahan Stunting dan Mengenali Penyebabnya. Sebelum penyuluhan dilakukan pre-test dan 
setelah penyuluhan dilakukan post-tes. Hal ini untuk menilai apakah sasaran dapat memahami materi yang telah diberikan penyuluhan. Sasaran dalam kegiatan pengabdian ini adalah ibu yang memiliki balita. Dalam pengabdian ini juga dilakukan evaluasi, input, proses dan output.

\section{Rancangan Evaluasi}

Evaluasi adalah penilaian terhadap penyerapan materi yang telah disampaikan kepada pengunjung diposyandu Desa Suka Mulya.Evaluasi dilaksanakan dalam bentuk mengulas kembali materi melalui diskusi dan Tanya jawab.

Adapun indikator pencapaian dan hasil evaluasi yaitu :

1. Para pengunjung mampu mengikuti penyuluhan dengan baik, rapi, tertib dan penuh semangat

2. Para pengunjung memahami tentang stunting melalui pertanyaan dan materi yang disampaikan oleh pemateri

3. Para pengunjung dapat menerapkan deteksi dini stunting.

\section{Metode Kegiatan}

Kegiatan pengabdian dilakukan dengan cara penyuluhan dan tanya jawab dengan mengangkat tema Pencegahan Stunting dan Mengenali Penyebabnya.
Setelah itu melakukan penimbangan berat badan dan pengukuran tinggi badan balita. Metode yang dilakukan dengan memberikan ceramah langsung dan leafleat berisi materi dan gambar yang menarik serta tanya jawab seputar stunting.

\section{HASIL}

Kegiatan yang dilakukan dalam penyuluhan ini dilaksanakan dalam beberapa tahap yang diawali dengan penyampaian materi terlebih dahulu, kemudian setelah diberikan materi melakukan seksitanya jawab serta diskusi.

Kegiatan penyuluhan ini dilaksanakan pada hari Rabu 17 Oktober 2018 bertempat di Desa Suka Mulya Kecamatan Bangkinang Kabupaten Kampar. Kegiatan ini memberikan hasil sebagai berikut :

Kelompok Penyaji

a. Berdasarkan hasil penyuluhan di Desa suka mulya, sudah terlihat bahwa kelompok penyaji mampu memberi sosialisasi mengenai stunting.

b. Media penyajian materi menggunakan flipchar.

Pengunjung Posyandu

a. Pengunjung memahami materi stunting yang disampaikan oleh pemateri 
b. Pengunjung yang hadir antusisa dalam mengikuti penyuluhan

c. Terjadi diskusi antara penyaji dan pengunjung

\section{PEMBAHASAN}

Kegiatan penyuluhan tentang stunting didesa suka mulya berjalan dengan baik. Hal ini terlihat dari ibu-ibu yang datang ke Posyandu tempat pelaksanaan pengabdian hadir tepat waktu dan antusias ibu-ibu dalam memberikan pertanyaan kepada penyaji. Selama ini, pengetahuan mereka hanya terbatas bahwa bayi yang telah mendapatkan MP-ASI boleh diberikan MP-ASI yang instan tidak dengan MPASI rumahan yang dibuat dengan menggunakan bahan dengan pemenuhan nutrisi yang lengkap. Dengan diadakan penyuluhan ini dapat dipastikan bahwa ibu-ibu mengetahui bahwa dengan pengolahan MP-ASI yang benar dapat mencegah terjadinya stunting.

\section{KESIMPULAN}

Dari kegiatan pengabdian diatas kita bisa menganbilan kesimpullan bahwa ASI eksklusif dan MP ASI sangat penting bagi pertumbuhan bayi dan balita untuk memenuhi keseimbangan gizi dan nutrisi bayi dan balita sehingga tidak terjadinnya gizi stunting atau pun gizi buruk pada bayidan balita. Serta mengenali tanda stunting sejak dini megurangi resiko kesakitan akibat gizi buruk dan sebagai ibu juga dapat mengetahui penyebab dan cara mencegah stunting.

\section{SARAN}

Dengan telah dilakukannya pengabdian tersebut maka diharapkan kepada puskesmmas agar dapat meningkatkan perhatiannya kepada balita yang mempunyai masalah dengan status gizi. Sebagai upaya pencegahan evaluasi yang digunakan dengan melakukan penimbangan berat badan dan pengukuran tinggi badan dan juga mengajarkan ibu tentang pemberian MPASI pada bayi dengan benar.

\section{DAFTAR PUSTAKA}

Adriani,M,. 2012.Peranan Gizi Dalam Siklus Kehidupan. Jakarta: Kencana Prenadamedia Group.

Astari, B.P. 2015. Hubungan antara praktik pemberian ASI eksklusif dan stunting pada anak usia $6-23$ bulan di Sumatera Barat. Jurnal Gizi dan Dietik Sumatera Barat. 3: 170-182.

I Dewa Nyoman Supariasa. Penilaian Status Gizi. Jakarta. Penerbit Buku Kedokteran EGC. 2002.

Onis, Md., Blossner, M., Borghi, E. 2011. Prevalence and Trends of Stunting among Pre-School Children, 1990- 
2020. Jornal of Public Health Nutrition. 15(1): 142-148.

Sudarti, Kendang. 2010. Asuhan Kebidanan Neonatus pada Bayi dan Anak Balita.Yogyakarta : Nuha Medika.
Semba, R. D. dan M. W. Bloem. 2001. Nutrition and Health in Developing Countries. New Jersey: Humana Press. 